\title{
Purification and Characterization of a Fucoidanase (FNase S) from a Marine Bacterium Sphingomonas paucimobilis PF-1
}

\author{
Woo Jung Kim ${ }^{1,2}$, Joo Woong Park ${ }^{1}$, Jae Kweon Park ${ }^{3}$, Doo Jin Choi ${ }^{1}$ and Yong Il Park ${ }^{1, *}$ \\ 1 Department of Biotechnology and The Biomaterial Engineering Research Center, \\ The Catholic University of Korea, Bucheon, Gyeonggi-do 420-743, Korea; \\ E-Mails:wj0504@gstep.re.kr (W.J.K.); pjwnbd@hanmail.net (J.W.P.); \\ myenwls@hanmail.net (D.J.C.) \\ 2 Biocenter, Gyeonggi Institute of Science and Technology Promotion (GSTEP), Suwon, \\ Gyeonggi-do 443-270, Korea \\ 3 Department of Pharmaceutical Science, University of Gachon, Yeonsu-dong, Yeonsu-gu, \\ InCheon 406-799, Korea; E-Mail: jkpark@gachon.ac.kr \\ * Author to whom correspondence should be addressed; E-Mail: yongil382@catholic.ac.kr; \\ Tel.: +82-2-2164-4512; Fax: +82-2-2164-4846.
}

Academic Editor: Antonio Trincone

Received: 30 May 2015/Accepted: 6 July 2015 / Published: 16 July 2015

Abstract: The Search for enzyme activities that efficiently degrade marine polysaccharides is becoming an increasingly important area for both structural analysis and production of lower-molecular weight oligosaccharides. In this study, an endo-acting fucoidanase that degrades Miyeokgui fucoidan (MF), a sulfated galactofucan isolated from the sporophyll (called Miyeokgui in Korean) of Undaria pinnatifida, into smaller-sized galactofuco-oligosaccharides (1000-4000 Da) was purified from a marine bacterium, Sphingomonas paucimobilis PF-1, by ammonium sulfate precipitation, diethylaminoethyl (DEAE)-Sepharose column chromatography, and chromatofocusing. The specific activity of this enzyme was approximately 112-fold higher than that of the crude enzyme, and its molecular weight was approximately $130 \mathrm{kDa}$ (FNase S), as determined by native gel electrophoresis and 130 (S1), 70 (S2) and 60 (S3) kDa by sodium dodecyl sulfate-polyacrylamide gel electrophoresis (SDS-PAGE). The optimum $\mathrm{pH}$ and temperature of FNase $\mathrm{S}$ were $\mathrm{pH}$ 6.0-7.0 and 40-45 ${ }^{\circ} \mathrm{C}$, respectively. FNase S activity was enhanced by $\mathrm{Mn}^{2+}$ and $\mathrm{Na}^{+}(115.7 \%$ and $131.2 \%)$, but it was inhibited by $\mathrm{Ca}^{2+}, \mathrm{K}^{+}, \mathrm{Ba}^{2+}$, $\mathrm{Cu}^{2+}\left(96 \%, 83.7 \%, 84.3 \%\right.$, and $89.3 \%$, respectively), each at $1 \mathrm{mM}$. The $K_{m}, V_{\max }$ and $K_{\text {cat }}$ values of FNase $\mathrm{S}$ on MF were $1.7 \mathrm{mM}, 0.62 \mathrm{mg} \cdot \mathrm{min}^{-1}$, and $0.38 \cdot \mathrm{S}^{-1}$, respectively. This 
enzyme could be a valuable tool for the structural analysis of fucoidans and production of bioactive fuco-oligosaccharides.

Keywords: fucoidan; Sphingomonas sp.; fucoidanase; galactofuco-oligosaccharides

\section{Introduction}

Fucoidans are a group of sulfated polysaccharides that exhibit various biological activities including anti-viral, anti-bacterial, anticoagulant and anti-tumoral activities [1-4]. The biological activities of fucoidans vary depending on the sources. The fucoidans of brown algae represent a family of homo- and hetero-polysaccharides that are mainly composed of fucose residues that are sulfated at positions 2 and/or 4 [5] and linked through $\alpha-1,2-$, $\alpha-1,3-$, or $\alpha-1,4-O$-glycosidic bonds [6,7]. Fucoidans have also been demonstrated to contain minor amounts of mannose, xylose, galactose, glucose, uronic acids, and rhamnose [8]. It is generally believed that monosaccharide composition and sulfate contents are related to the different biological activities of fucoidans.

Despite their diverse pharmacologic activities, the structural variation, high molecular masses, and viscous nature of polysaccharides including marine-derived ones may limit their successful applications, especially as therapeutic agents, in terms of problems in polysaccharide standardization, solubility, and bioavailability [9,10]. Bioactive oligosaccharides with lower-molecular weights would help overcome these problems. Indeed, recently, significant efforts have been made to prepare oligosaccharides from marine polysaccharides, aiming at the pharmaceutical usage of bioactive oligosaccharides [8-12]. For example, the fuco-oligosaccharides produced by the hydrolysis of fucoidan with fucoidanases have been applied as pharmaceutical materials in medical sciences [13]. On the other hand, fucoidanases can be either exo- or endo-acting enzymes. However, no commercial endo-fucosidases [5] are currently available.

Therefore, searching for new enzyme activities that degrade marine polysaccharides becomes increasingly important area for both academic researchers and industry people. Especially, finding new fucoidanases and their subsequent kinetic characterizations would provide not only insight into the relationships between the structures and the biological activities of fucoidans but also improved technologies for the production of industrially important bioactive fuco-oligosaccharides [11]. Thus, enzymes having fucoidan-degrading activities have been sought for enzymatic modifications of fucoidans for the preparation of lower-molecular weight fuco-oligosaccharides. The major advantage for the enzymatic digestion over the chemical cleavage is the preservation of sulfate groups on fucoidans, which are recognized as the major factors implicated in the various biological activities of sulfated polysaccharides (SPS).

Previously, we reported on the isolation and identification of a marine bacterial strain, Sphingomonas paucimobilis PF-1, that degrades the Miyeokgui fucoidan (MF), which was purified in house from the sporophyll (commonly called Miyeokgui in Korean and Mekabu in Japanese) of Korean Undaria pinnatifida [14]. When intact cells of this strain was used as an enzyme source and incubated with MF as the substrate, seven distinct low-molecular weight fuco-oligosaccharides (LMFOs) with masses lower than approximately $4 \mathrm{kDa}$, were produced [14]. On the other hand, we also reported that 
the MF fucoidan is actually an $O$-acetylated sulfated galactofucan polysaccharide with a molecular mass of $1246 \mathrm{kDa}$, as characterized by various methods, such as organic elemental analysis, high performance liquid chromatography (HPLC) analysis of neutral sugars, Fourier transform infrared spectroscopy (FTIR), FT-Raman (Fourier transform-Raman), ${ }^{1} \mathrm{H}$ and ${ }^{13} \mathrm{C}$ nuclear magnetic resonance (NMR) [15].

In the present study, we first report on the purification and characterization of a fucoidanase (FNase S) from Sphingomonas paucimobilis PF-1, which degrades the high-molecular weight fucoidan (MF) into low-molecular weight galactofuco-oligosaccharides.

\section{Results and Discussion}

\subsection{Enzyme Purification}

Fucodianase was purified from the supernatant that was prepared from the cell harvest via ammonium sulfate fractionation, diethylaminoethyl (DEAE)-Sepharose Fast-Flow anion-exchange chromatography and chromatofocusing. Consequently, the elution profile of the DEAE Sepharose chromatography indicated that among the five peaks with fucoidanase activities, fractions 2 to 8 (peak I) exhibited relatively higher peak than the others (Figure 1A). The fractions in peak I were collected and concentrated with $80 \%\left(\mathrm{NH}_{4}\right)_{2} \mathrm{SO}_{4}$. The elution profile from the chromatofocusing revealed a single peak with fucoidanase activity that appeared from fractions 71 to 75 (Figure 1B). These results, summarized in Table 1, indicate that the enzyme was purified to homogeneity, and a 112.8-fold increase in the specific fucoidanase activity (relative to the activity of the cell disruption supernatant) with a yield of approximately $3.2 \%$. Notably, all of the processes employed in the purification step may provide useful tools for the purification of those displayed on the cell surface since we previously reported that this fucoidan-degrading enzyme activity of $S$. paucimobilis PF-1 is observed with the harvested intact cells, implying its localization on the surface of the cell [14].

(A)

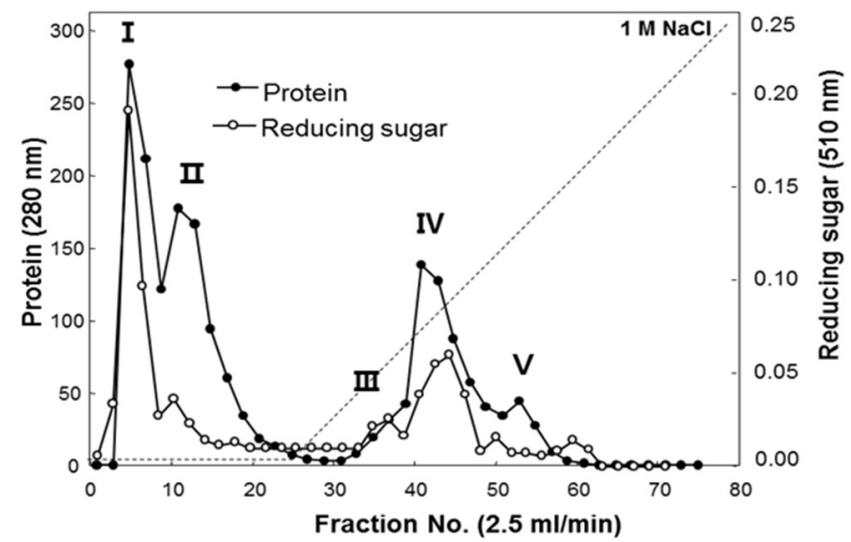

(B)

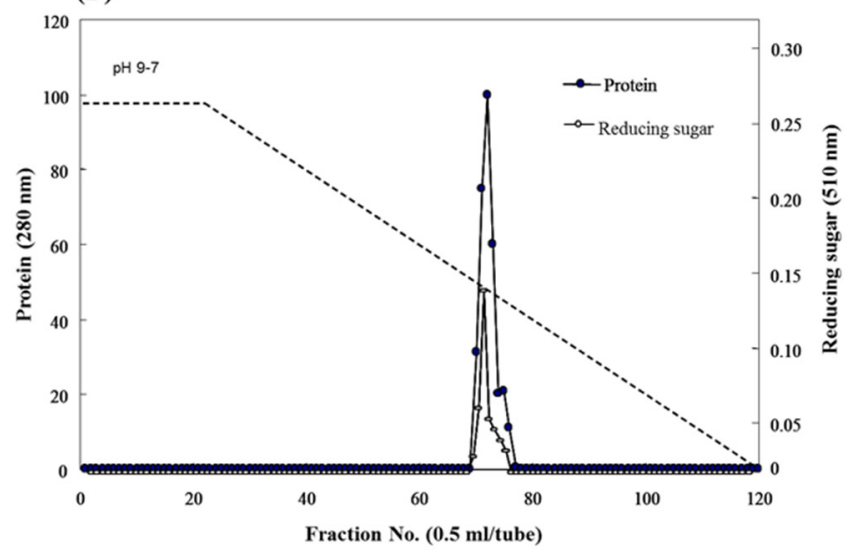

Figure 1. Elution profiles of the fucoidanase from Sphingomonas paucimobilis PF-1 resulting from (A) diethylaminoethyl (DEAE)-Sepharose fast-flow anion exchange column chromatography and (B) chromatofocusing. 
Table 1. Isolation and purification of fucoidanase from Sphingomonas paucimobilis PF-1.

\begin{tabular}{|c|c|c|c|c|c|c|c|}
\hline Step & $\begin{array}{c}\text { Total volume } \\
(\mathrm{mL}) \\
\end{array}$ & $\begin{array}{l}\text { Protein } \\
(\mathrm{mg} / \mathrm{mL})\end{array}$ & $\begin{array}{c}\text { Total protein } \\
(\mathbf{m g}) \\
\end{array}$ & $\begin{array}{l}\text { Activity } \\
\text { (mg/mL) }\end{array}$ & $\begin{array}{c}\text { Specific activity } \\
\left(\mathrm{U} \cdot \mathrm{mg}^{-1} \text { of protein }\right)\end{array}$ & $\begin{array}{c}\text { Total activity } \\
\text { (unit) }\end{array}$ & $\begin{array}{l}\text { Yield } \\
(\%) \\
\end{array}$ \\
\hline $\begin{array}{l}\text { Cell disruption } \\
\text { supernatant }\end{array}$ & 100 & 44.287 & 4428.7 & 0.841 & 0.019 & 84.08 & 100 \\
\hline $\begin{array}{c}80 \% \text { Ammonium } \\
\text { sulfate }\end{array}$ & 70 & 19.582 & 1370.74 & 0.538 & 0.027 & 37.66 & 44.79 \\
\hline DEAE-Sepharose & 15 & 0.147 & 2.205 & 0.210 & 1.429 & 3.15 & 3.75 \\
\hline Chromatofocusing & 3 & 0.042 & 0.126 & 0.090 & 2.143 & 0.27 & 3.2 \\
\hline
\end{tabular}

\subsection{Estimation of the Molecular Mass and N-Terminal Sequence of the Fucoidanase}

To determine the protein purity and molecular mass of the purified enzyme, native-polyacrylamide gel electrophoresis (PAGE) and sodium dodecyl sulfate (SDS)-PAGE was used according to the methods described by Laemmli [16]. The results shown in Figure 2A indicated that there was one single protein band from the final concentrated elutant, and the relative molecular mass of the purified fucoidanase was estimated to be $130 \mathrm{kDa}$ (FNase S) with native-PAGE. It has been reported that the majority of Flavobacteriaceae sp. fucoidanases have molecular masses of $105 \mathrm{kDa}$, based on SDS-PAGE [17]. In general, the high-molecular weight enzyme (e.g., FNase S) can be dissociated by treatment with SDS and boiling for 10 min into several components that can be separated with SDS-PAGE. To determine whether the protein was monomeric, the purified enzyme was analyzed with SDS-PGAE. As shown in Figure 2B, the isolated multi-complex enzyme exhibited three subunits that were derived from the purified enzyme, appeared as a single band in the native-PAGE, and were determined to have molecular weights of 130 (S1), 70 (S2), and $60 \mathrm{kDa}$ (S3) by SDS-PAGE. A similar result was reported by another research group. Furukawa et al. [18] reported that the molecular masses of the fucoidanase E1, E2, and E3 of the Vibrio sp. N-5 were $39 \mathrm{kDa}, 68 \mathrm{kDa}$, and $68 \mathrm{kDa}$, respectively, based on SDS-PAGE analysis. Although the evidence is insufficient to reach a clear conclusion, these results indicated that the purified fucoidanases from both of the bacterial strains appeared to be similar to the large extracellular enzyme complex, called the cellulosome, of the plant-cell-wall-degrading anaerobic microorganisms [19]. The cellulosome consists of a scaffolding protein and many bound enzymes. Similarly, the subunits of FNase S of Sphingomonas paucimobilis PF-1 are probably involved in the enzyme's activity, stability and/or binding to substrate in physiological conditions.

The $N$-terminal 10-amino acid sequences of the S1, S2, and S3 subunits were analyzed and determined to be SXPEAASLPG, SPQFDVVXIG, and SLQFDVVVIG, respectively. A BLASTp search of GENBANKnr using the three domains revealed homologies primarily with hypothetical bacterial conserved proteins, with various annotations, such as protein-containing ATPase, core domain (EGF 27867), carbohydrate kinase, PfkB family protein (YP003854323) and dihydrolipoyl dehydrogenase (ZP08017938) (Table 2), which are not related to any glycohydrolases or glycosidases. Based on these results, we suggest that the purified protein might be a unique enzyme with fucoidanase activity, although full amino acid sequences of these subunits need to be further determined in the future. 
Table 2. Determinations of the $N$-terminal amino acid sequences of (A) S1, (B) S2, and (C) S3. The isolated multi-complex enzyme was composed of three subunits with molecular weights of 130 (S1), 70 (S2), and $60 \mathrm{kDa}$ (S3), as determined with SDS-PAGE.

\begin{tabular}{|c|c|c|c|c|c|c|}
\hline Matched protein & $\begin{array}{c}\text { Mol. Mass } \\
\text { (kDa) }\end{array}$ & Positives (\%) & Matched species & $\begin{array}{c}\text { Functional } \\
\text { category }\end{array}$ & Matched Peptide & Accession No. \\
\hline \multicolumn{7}{|c|}{ (A) The homology comparison of $N$-terminal 10 -amino acid sequence of the $\mathrm{S} 1$ subunit to the hypothetical bacterial conserved proteins by a BLASTp search } \\
\hline $\begin{array}{l}\text { Protein containing ATPase, } \\
\text { AAA+ type, core domain }\end{array}$ & 244 & $8 / 10(80)$ & $\begin{array}{c}\text { Rhodopirellula baltica } \\
\text { WH47 }\end{array}$ & $\begin{array}{l}\text { Protein containing } \\
\text { ATPase, core domain }\end{array}$ & maedaspeaaslpgaagdgg & EGF 27867 \\
\hline Hypothetical protein RB6669 & 202 & $8 / 10(80)$ & Rhodopirellula baltica SH 1 & ATP binding site & maedaspeaaslpgaagdgg & NP 867389 \\
\hline Chitinase & 127 & $8 / 10(80)$ & $\begin{array}{c}\text { Arthroderma otae } \\
\text { CBS } 113480\end{array}$ & & wpdvldaaslptltletagg & XР002842640 \\
\hline $\begin{array}{c}\mathrm{ABC} \text { sugar (glycerol) } \\
\text { transporter, inner membrane } \\
\text { subunit }\end{array}$ & 32 & $8 / 10(80)$ & Sagittula stellata E-37 & $\begin{array}{l}\text { Inner membrane } \\
\text { subunit }\end{array}$ & madttsapgaaslpgdvtak & ZP01747232 \\
\hline $\begin{array}{c}\text { Glycoside hydrolase } \\
\text { family protein }\end{array}$ & 103 & $8 / 10(80)$ & $\begin{array}{c}\text { Roseiflexus castenholzii } \\
\text { DSM } 13941\end{array}$ & Sugar binding domain & slsdgpesaslpgrfplret & YP001433316 \\
\hline \multicolumn{7}{|c|}{ (B) The homology comparison of $N$-terminal 10-amino acid sequence of the $\mathrm{S} 2$ subunit to the hypothetical bacterial conserved proteins by a BLASTp search } \\
\hline $\begin{array}{c}\text { Carbohydrate kinase, PfkB } \\
\text { family protein }\end{array}$ & 34 & $8 / 10(80)$ & $\begin{array}{c}\text { Parvularcula bermudensis } \\
\text { HTCC } 2503\end{array}$ & Adenosine_kinase & mapqfdviaignaivdllah & YP003854323 \\
\hline $\begin{array}{c}\text { Hypothetical protein } \\
\text { DFA_11777 } \\
\end{array}$ & 78 & $9 / 10(90)$ & Dictyostelium fasciculatum & Hypothetical protein & mvsphydvvvigagiaglsq & EGG14015 \\
\hline $\begin{array}{l}\text { Dihydrolipoamide } \\
\text { dehydrogenase }\end{array}$ & 50 & $8 / 10(80)$ & $\begin{array}{l}\text { Xanthomonas axonopodis } \\
\text { pv. citri str. } 306\end{array}$ & $\begin{array}{c}\text { Pyridine nucleotide- } \\
\text { disulphide } \\
\text { oxidoreductase }\end{array}$ & mseqfdvvvigagpagyhaa & NP641866 \\
\hline Sugar kinase & 34 & $8 / 10(80)$ & Erythrobacter sp. SD-21 & Adenosine kinase & mtdprydvvaignaivdvma & ZP01863524 \\
\hline
\end{tabular}


Table 2. Cont.

\begin{tabular}{|c|c|c|c|c|c|c|}
\hline Matched protein & $\begin{array}{c}\text { Mol. Mass } \\
\text { (kDa) }\end{array}$ & Positives (\%) & Matched species & Functional category & Matched Peptide & Accession No. \\
\hline \multicolumn{7}{|c|}{ (C) The homology comparison of $N$-terminal 10 -amino acid sequence of the $\mathrm{S} 3$ subunit to the hypothetical bacterial conserved proteins by a BLASTp search } \\
\hline Dihydrolipoyl dehydrogenase & 51 & $9 / 10(90)$ & $\begin{array}{c}\text { Lautropia mirabilis ATCC } \\
51599 \\
\end{array}$ & $\begin{array}{c}\text { Dihydrolipoyl } \\
\text { dehydrogenase }\end{array}$ & mslefdvvvigagpggyiaa & ZP08017938 \\
\hline $\begin{array}{c}\text { Anaerobic glycerol-3- } \\
\text { phosphate dehydrogenase } \\
\text { subunit B }\end{array}$ & 45 & $9 / 10(90)$ & $\begin{array}{l}\text { Serratia odorifera DSM } \\
45822\end{array}$ & $\begin{array}{c}\text { ANAEROBIC } \\
\text { glycerol-3-phosphate } \\
\text { dehydrogenase }\end{array}$ & mqfdvvvigg & ZP06638221 \\
\hline Transmembrane protein & 42 & $9 / 10(90)$ & $\begin{array}{l}\text { Chromobacterium } \\
\text { violaceum } \\
\text { ATCC } 12472\end{array}$ & Transmembrane protein & mqfdviviga & NP902173 \\
\hline
\end{tabular}

$\mathrm{AAA}+$, ATPases associated with various cellular activities; ABC, ATP-binding cassette. 


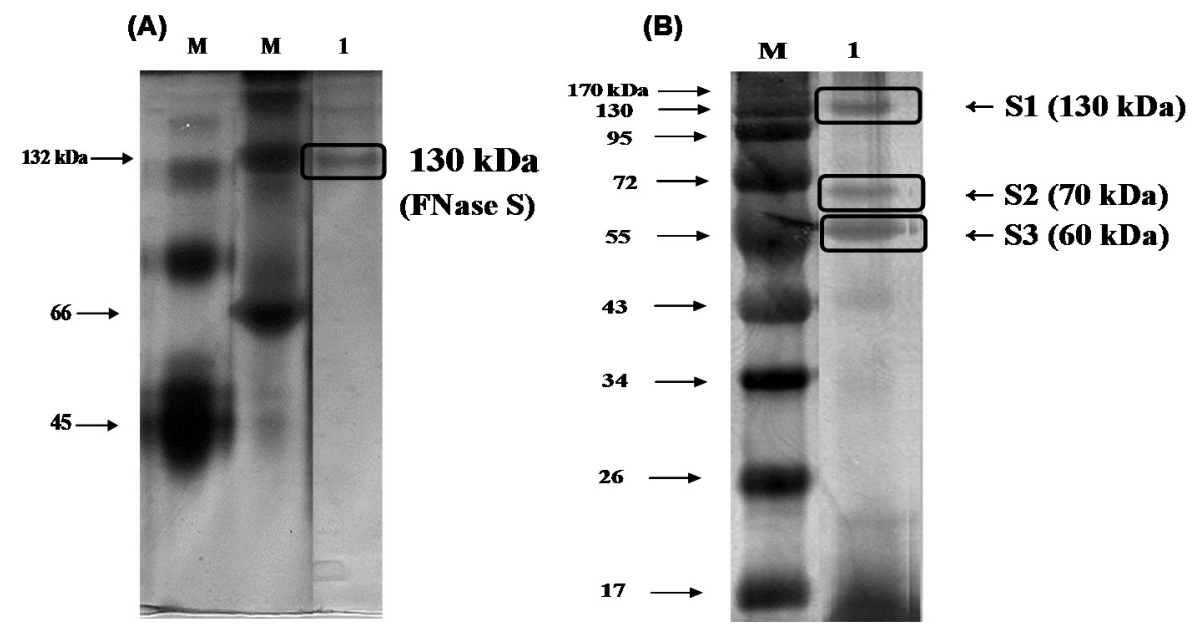

Figure 2. Gel-electrophoresis analyses of the purified enzyme. The purified fucoidanase was analyzed with (A) 12\% native-polyacrylamide gel electrophoresis (PAGE) and (B) sodium dodecyl sulfate (SDS)-PAGE, and stained with silver. M, molecular weight marker $(\mathrm{kDa})$; lane 1, purified fucoidanase on the native-PAGE (A); lane 1, purified fucoidanase on the SDS-PAGE performed without mercaptoethanol in the sample buffer $(\mathbf{B})$.

\subsection{Optimum $\mathrm{pH}$ and Temperature for Enzyme Activity and Stability}

The FNase $\mathrm{S}$ activity was measured at various $\mathrm{pH}$ values $(\mathrm{pH}$ 4.0 9.0) in buffers with the same ionic concentrations to determine the optimal conditions. The $\mathrm{pH}$ stability was tested via $24-\mathrm{h}$ preincubations of the FNase $\mathrm{S}$ in appropriate buffers at $45{ }^{\circ} \mathrm{C}$ that had the same ionic concentrations but different $\mathrm{pH}$ values that ranged from 4.0 to 9.0. The maximum activity was observed between pH 6.0 and 7.0 (Figure 3A). The FNase $\mathrm{S}$ activity was measured as a function of temperature from $25^{\circ} \mathrm{C}$ to $55^{\circ} \mathrm{C}$, and the activity was found to be greatest at $45^{\circ} \mathrm{C}$ (Figure 3B). The thermostability was tested after preincubation at various temperatures $\left(25-55^{\circ} \mathrm{C}\right)$ for one day at $\mathrm{pH} 6.0$ and then by measuring the residual fucoidanase activity at $45{ }^{\circ} \mathrm{C}$. As shown in Figure 3B, this enzyme was shown to be stable at $40-45^{\circ} \mathrm{C}$. The optimum $\mathrm{pH}$ and temperature for this enzyme were very close to the enzyme of the marine Vibrio sp., which has optimum $\mathrm{pH}$ and temperature ranges of $\mathrm{pH} 6.0$ to 8.0 and 35 to $45^{\circ} \mathrm{C}$, respectively [18]. 

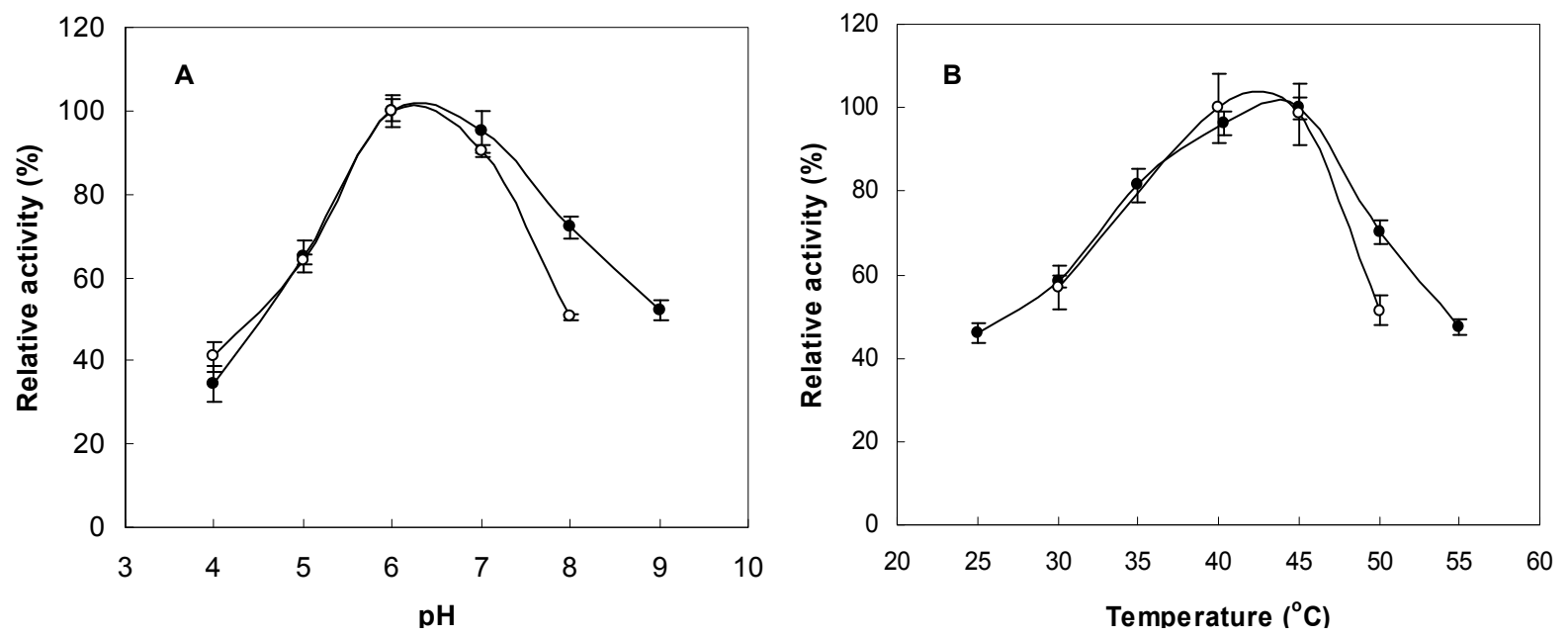

Figure 3. Effects of $\mathrm{pH}$ and temperature on enzyme activity and stability. (A) The enzyme activities were measured at various $\mathrm{pH}$ levels at $45{ }^{\circ} \mathrm{C}$ for three days $(\bullet)$. The enzyme solutions were preincubated at various $\mathrm{pH}$ levels for one day, and the remaining activities were measured at $\mathrm{pH} 6.0$ and $45^{\circ} \mathrm{C}$ for three days (o). (B) The enzyme activities were measured at various temperatures in $10 \mathrm{mM}$ sodium acetate buffer at a $\mathrm{pH}$ of 6.0 for three days $(\bullet)$. The enzyme solutions were preincubated at various temperatures for one day in $10 \mathrm{mM}$ sodium acetate buffer $(\mathrm{pH} 6.0)$, and the remaining activities were measured at $45^{\circ} \mathrm{C}$ for three days (०).

\subsection{Effects of Meal Ions and Substrate Specificities on the Enzyme Activities}

The effects of metal ions on activity of FNase $\mathrm{S}$ were investigated (Table $3 \mathrm{~A}$ ). $\mathrm{Mn}^{2+}$ and $\mathrm{Na}^{+}$ (concentrations of $1 \mathrm{mM}$ ) caused significant increases of $115 \%$ and $131 \%$, respectively, while $\mathrm{Ca}^{2+}$ $(86 \%), \mathrm{K}^{+}(83 \%), \mathrm{Ba}^{2+}(84 \%)$ and $\mathrm{Cu}^{2+}(89 \%)$ caused significant decreases in enzyme activity. FNase $\mathrm{S}$ may require mono- or divalent metal ions $\left(\mathrm{Mn}^{2+}\right.$ and $\left.\mathrm{Na}^{+}\right)$for effective enzyme activity or digestion of Miyeokgui fucoidan (MF) via the metabolic processes that occur in marine environments. The substrate specificities of FNase $\mathrm{S}$ on various carbohydrates were investigated (Table 3B). A commercial fucoidan (FF, Sigma, St. Louis, MO, USA) and alginate stimulated the FNase S enzyme activity by $134 \%$ and $129 \%$, respectively, when compared with that $(100 \%)$ on MF as the control. However, heparin (79\%), starch (25\%), laminarin (54\%) and dextran (15\%) acted to decrease the activity of FNase S. Therefore, we concluded that FNase S exhibits substrate specificities for fucoidan and alginate. However, to more clearly define the relationships between the molecular structures of these polysaccharides and the enzyme activities, additional comparison studies with other fucoidanases are needed. Unfortunately, to date, less is known about the enzymatic properties of fucoidanases. It is very important to achieve a detailed understanding of the key factors, such as the sulfur content, the sugar composition and the molecular weight, of substrates involved in the enzymatic characteristics. 
Table 3. Effects of metal ions (A) and substrate specificities (B) on fucoidanase activities. The data are given as the means $\pm \mathrm{SD}$ (standard deviation), $n=3$. (A) Control, the fucoidanase activity in the absence of metal ions was regarded as $100 \%$. (B) Control, the activity of the purified enzyme (FNase S) on MF was regarded as $100 \%$.

\begin{tabular}{cc}
\hline Metal ions (1 $\mathbf{~ m M})$ & Relative activity (\%) \\
\hline (A) Effects of metal ions on fucoidanase activities. \\
\hline Control & 100 \\
$\mathrm{Na}^{+}$ & $131.2 \pm 0.83$ \\
$\mathrm{Mn}^{2+}$ & $115.7 \pm 0.93$ \\
$\mathrm{~K}^{+}$ & $83.7 \pm 0.26$ \\
$\mathrm{Cu}^{2+}$ & $89.3 \pm 2.06$ \\
$\mathrm{Ca}^{2+}$ & $86 \pm 1.68$ \\
$\mathrm{Ba}^{2+}$ & $84.3 \pm 2.8$ \\
\hline
\end{tabular}

(B) Effects of substrate specificities on fucoidanase activities.

\begin{tabular}{cc}
\hline Substrate & Relative activity (\%) \\
Control & 100 \\
FF $^{*}$ & $134.5 \pm 1.9$ \\
Heparin & $79.2 \pm 1.4$ \\
Alginate & $129.4 \pm 2.3$ \\
Starch & $25.2 \pm 0.8$ \\
Laminarin & $54.9 \pm 2.2$ \\
Dextran & $15.5 \pm 3.1$ \\
\hline
\end{tabular}

* FF, a commercial fucoidan (Sigma).

\subsection{Kinetic Parameters}

Initially, the kinetic parameters of the FNase $\mathrm{S}$ against the natural substrates, FF and MF, were determined to be $K_{\mathrm{m}}=1.7$ and $1.8 \mathrm{mM}$, and $V_{\max }=0.62$ and $0.64 \mathrm{mg} / \mathrm{min}$, respectively (Figure 4). These results also indicated that the $K_{\text {cat }}$ values of the FNase S were $0.376 \mathrm{~S}^{-1}$ and $0.343 \mathrm{~S}^{-1}\left(V_{\max } / K_{\mathrm{m}}\right)$, respectively (Table 4). Interestingly, MF and FF were hydrolyzed at similarly fast rates $\left(K_{\text {cat }}\right)$ and high $K_{\text {cat }} / K_{\mathrm{m}}$ values. As demonstrated in Figures 3 and 4, the determination of the kinetic parameters and substrate specificities of FNase S are important for understanding its enzymatic properties. However, our ability to find valuable information from other comparable studies was limited due to the paucity of such studies. Therefore, our current date could be the most valuable in terms of its contributions to kinetic studies of the activities of fucoidanases and other related enzymes. 

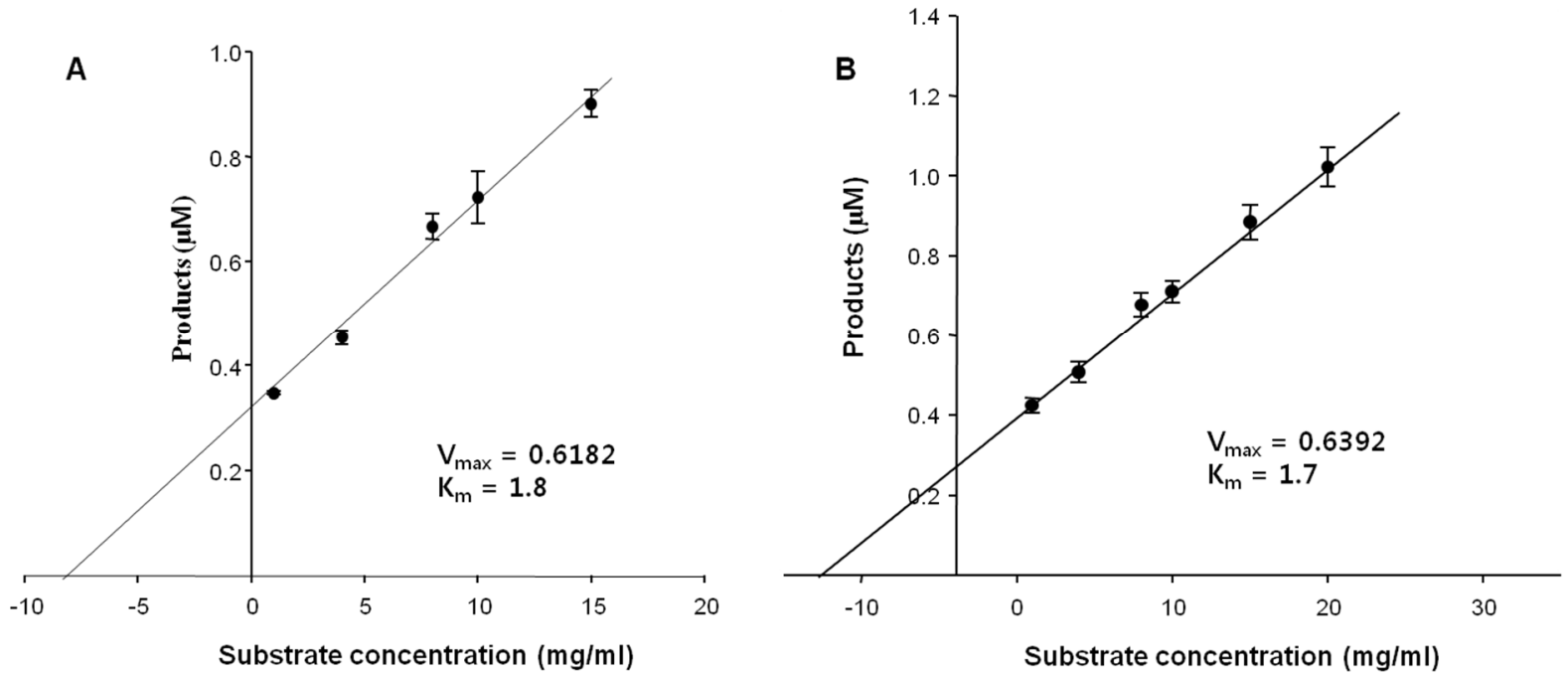

Figure 4. Assay of the enzyme kinetics at different substrate concentrations. The concentration of the enzyme was fixed at $1 \mathrm{mg} / \mathrm{mL}$. (A) Miyeokgui fucoidan (MF) and (B) FF (commercial fucoidan, Sigma) were used as the substrates. The values of the products were calculated by measuring the reducing sugars released from the substrate fucoidans, (A) MF and (B) FF, and were expressed in molar concentrations.

Table 4. Kinetic parameters of the purified enzyme (FNase S) on Miyeokgui fucoidan (MF) and commercial fucoidan (FF) as the substrates.

\begin{tabular}{ccccc}
\hline Substrate & $\boldsymbol{K}_{\text {cat }}\left(\mathbf{S}^{-\mathbf{1}}\right)$ & $\boldsymbol{K}_{\mathrm{m}}(\mathbf{m M})$ & $\boldsymbol{V}_{\max }(\mathbf{m g} / \mathbf{m i n})$ & $\boldsymbol{K}_{\text {cat }} / \boldsymbol{K}_{\mathbf{m}}\left(\mathbf{S}^{-\mathbf{1}} \cdot \mathbf{m M}^{-\mathbf{1}}\right)$ \\
\hline FF & $0.376 \pm 0.04$ & $1.7 \pm 0.36$ & 0.62 & 0.221 \\
MF & $0.343 \pm 0.1$ & $1.8 \pm 0.25$ & 0.64 & 0.19 \\
\hline
\end{tabular}

FF, commercial fucoidan (Sigma); MF, Miyeokgui fucoidan.

\subsection{Production and Characterization of Galactofuco-Oligosaccharides by FNase S}

The fucoidanase activity was determined by measuring the level of reducing sugars and confirmed by HPLC analyses of the degradation products (Figure 5). The fucoidan-degrading activity was also clearly confirmed by the fractionation of the degradation products through Bio-Gel P-4 size-exclusion chromatography and the analysis of the monosaccharide compositions of the resulting oligosaccharides (Figure 6). The oligosaccharides generated were resolved into seven distinct low-molecular mass fractions with peaks that ranged from 1 to 7 . Based on comparisons with the masses of the standard malto-oligosaccharides (1-7 glucose units, Sigma), the relative molecular masses of these fucoidan oligosaccharides were determined to be 3312 Da (peak 1), 2494 Da (peak 2), 1699 Da (peak 3), $1543 \mathrm{Da}$ (peak 4), $1312 \mathrm{Da}$ (peak 5), $817 \mathrm{Da}$ (peak 6), and $318 \mathrm{Da}$ (peak 7) (Table 5). Based on the total sugar levels, one major fraction (peak 2) represented approximately $72 \%$ of the initial oligosaccharide mixture. Based on the high performance anion-exchange chromatography with pulsed amperometric detection (HPAEC/PAD) analysis that followed trifluoroacetic acid (TFA) hydrolysis, the constituent monosaccharides of these seven major oligosaccharides were determined to be the following: peak 1, fucose, galactose, mannose and xylose at 8:7:2:2 (given as the mole ratios); peak 2, $3: 8: 2: 2$; peak 3 , 5:3:1:1; peak $4,3: 3: 2: 1$; peak 5 , fucose and galactose at $7: 1$; peak 6 , fucose and 
galactose, 4:1; peak 7, fucose only (dimer) (Table 5). The uronic acid and sulfate contents of these fractions were not determined at this time. These results clearly indicated that fucose and galactose were the major monosaccharides in these oligosaccharides that were derived from MF fucoidan.

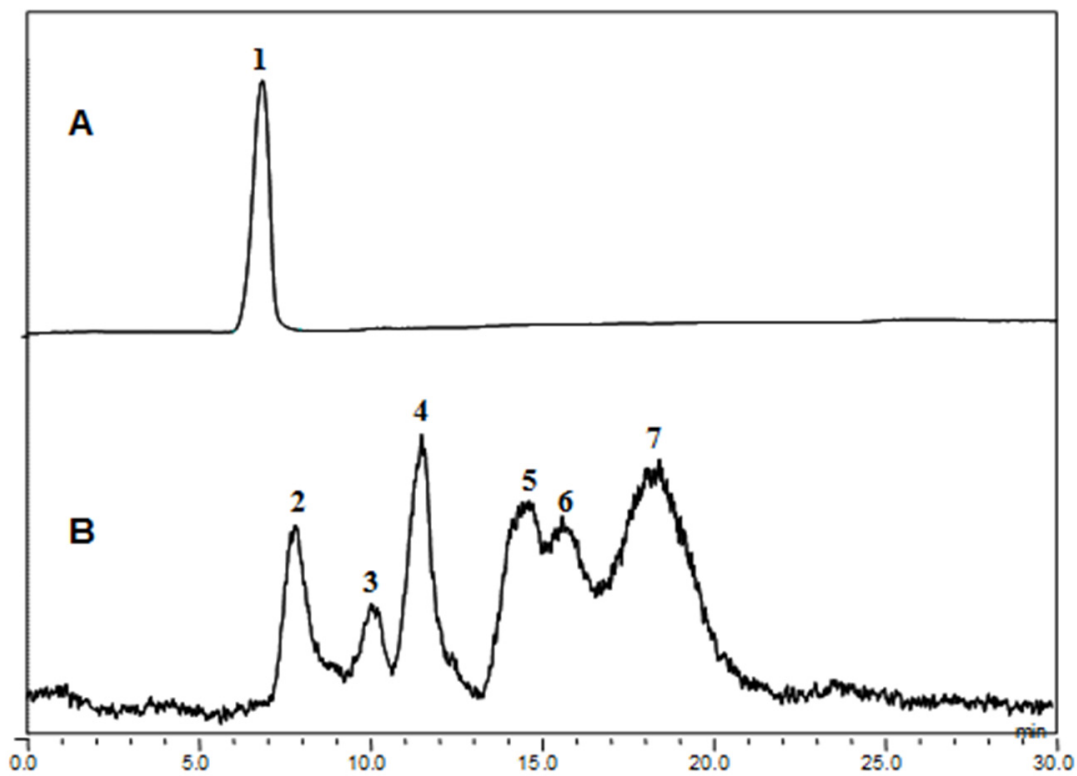

Figure 5. High performance liquid chromatography (HPLC) analysis of Miyeokgui fucoidan (MF) and its enzymatic hydrolysates produced by FNase S. (A) MF and (B) its hydrolysates were analyzed on a Shodex OHpak SB-806HQ column using HPLC system equipped with evaporative light scattering detector (ELSD). The elution was performed with distilled water at a rate of $0.8 \mathrm{~mL} / \mathrm{min}$.

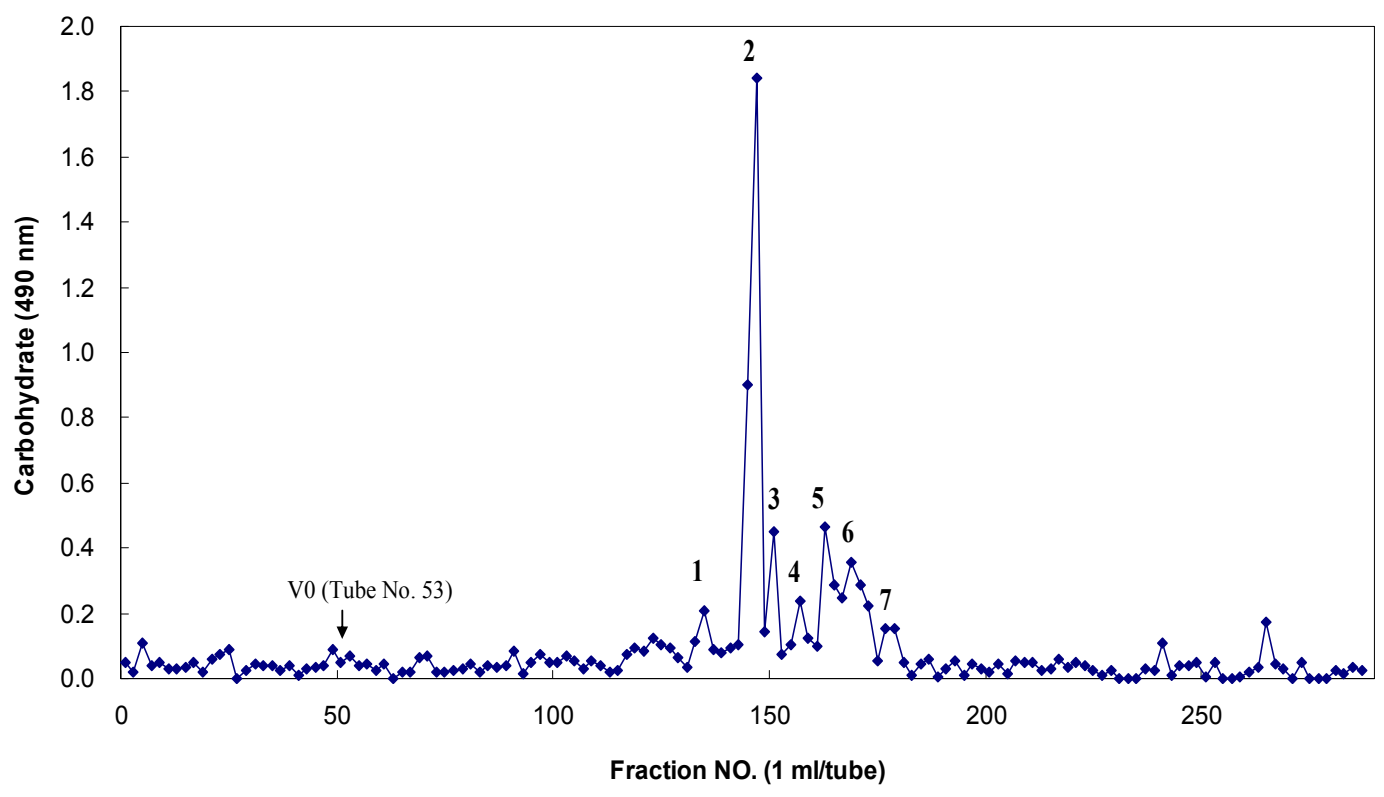

Figure 6. Bio-Gel P-4 column chromatography of the fragmented Miyeokgui fucoidan (MF) after digestion by FNase S. 
Table 5. Monosaccharide compositions and relative molecular masses of the galactofuco-oligosaccharides generated from MF by FNase S.

\begin{tabular}{|c|c|c|c|}
\hline Peak No ${ }^{a}$ & $M_{r}^{b}(D a)$ & Monosaccharide composition $^{c}$ & Relative amount (\%) ${ }^{d}$ \\
\hline 1 & 3312 & $\begin{array}{l}\text { Fucose, Galactose, Mannose, Xylose } \\
\text { (mole ratio, 8:7:2:2) }\end{array}$ & 4.5 \\
\hline 2 & 2494 & $\begin{array}{l}\text { Fucose, Galactose, Mannose, Xylose } \\
\text { (mole ratio, 3:8:2:2) }\end{array}$ & 72 \\
\hline 3 & 1699 & $\begin{array}{l}\text { Fucose, Galactose, Mannose, Xylose } \\
\text { (mole ratio, } 5: 3: 1: 1 \text { ) }\end{array}$ & 6.5 \\
\hline 4 & 1543 & $\begin{array}{l}\text { Fucose, Galactose, Mannose, Xylose } \\
\text { (mole ratio, } 3: 3: 2: 1 \text { ) }\end{array}$ & 2.7 \\
\hline 5 & 1312 & $\begin{array}{l}\text { Fucose, Galactose } \\
\text { (mole ratio, } 7: 1 \text { ) }\end{array}$ & 5.3 \\
\hline 6 & 817 & $\begin{array}{l}\text { Fucose, Galactose } \\
\text { (mole ratio, } 4: 1 \text { ) }\end{array}$ & 6.1 \\
\hline 7 & 318 & Fucose (2 moles) & 2.9 \\
\hline \multicolumn{4}{|c|}{$\begin{array}{l}\text { a The oligosaccharides were fractionated through a Bio-Gel P- } 4 \text { column after digestion of MF by FNase S; } \\
\text { b The relative molecular mass of each oligosaccharide was estimated using malto-oligosaccharides } \\
\text { (1-7 glucose units, Sigma) as standard molecular markers; }{ }^{c} \text { The monosaccharide compositions were } \\
\text { determined with high performance anion-exchange chromatography with pulsed amperometric detection } \\
\text { (HPAEC-PAD) analyses; }{ }^{d} \text { The carbohydrate contents of each peak were the total neutral sugars as } \\
\text { determined with the phenol-sulfuric acid method and the relative amounts of each oligosaccharide were } \\
\text { estimated by setting the sum of the major oligosaccharides (peak } 1-7) \text { to } 100 \% \text {. }\end{array}$} \\
\hline
\end{tabular}

This fucoidanase activity of FNase $\mathrm{S}$ was not related to $\alpha$-L-fucosidase. While the commercial $\alpha$-L-fucosidase released $p$-nitrophenol from the artificial substrate, $p$-nitrophenyl- $\alpha$-L-fucoside, our fucoidanase enzyme preparation (FNase S) did not produce $p$-nitrophenol, which demonstrated that the fucoidanase activity of this enzyme in the degradation of MF was not related to the $\alpha$-L-fucosidase activity (data not shown). Taken collectively, these results strongly suggested that FNase $\mathrm{S}$ produces low-molecular weight galactofuco-oligosaccharides from MF, a sulfated galactofucan of the sporophyll (called Miyeokgui in Korean) of Korean Undaria pinnatifida, and that this FNase S is not an $\alpha$-L-fucosidase but is rather an endo-acting fucoidanase that randomly attacks the fucoidan chains as other reports have demonstrated $[8,20]$.

Bakunina [21] reported on the 25 strains of epiphytic marine bacteria isolated from the brown algae Fucus evanescens and Chorda filum, and 53 bacterial strains isolated from the sea cucumber Apostichopus japonicus were screened for having fucoidanase activity using fucoidans prepared from the brown algae $F$. evanescens and Laminaria cichorioides (Table 6). The bacterial epiphytes Cytophaga sp. and some bacterial isolates of the genera Alteromonas and Pseudoalteromonas from the sea cucumber were also found to possess fucoidanase activity [13]. However, the enzyme activity was comparable but lower than that of the already known microbial fucoidanases [22,23]. Although very little is known about the genes that encode fucoidanases, the molecular cloning and biochemical characterization of a special fucanase FenA termed fucan $\alpha$-1,4-endohydrolase isolated from the family Flavobacteriaceae have decoded the structural basis of sulfated polysaccharides [17,24]. The results of this study demonstrated that our FNase S produces low-molecular weight galactofuco-oligosaccharides 
from fucoidan (actually a sulfated galactofucan). However, these results raise the questions on how bacteria that produce fucoidanase can take up dimer and larger oligosaccharides into the cytoplasmic space through the cell wall for use as nutrients. Additional studies of the catabolic cascade of MF and its oligomers are underway. In addition, mining and molecular cloning of corresponding genes for FNase $\mathrm{S}$ in the future would stimulate the applicability of this enzyme to the various industries for the development of new nutraceuticals, cosmeceuticals, as well as pharmaceuticals.

Table 6. Fucoidan-degrading enzymes and their properties.

\begin{tabular}{|c|c|c|c|c|c|}
\hline $\begin{array}{c}\text { Producing } \\
\text { microorganism }\end{array}$ & MW (Da) & Habitat & Substrate & Cleaving pattern & Refs. \\
\hline $\begin{array}{c}\text { Cytophaga, Alteromonas, } \\
\text { Pseudoalteromonas }\end{array}$ & n.d. & Intra-cellular & $\begin{array}{c}\text { Fucoidan from Fucus } \\
\text { evanescens, Laminaria } \\
\text { cichorioides and } \\
\text { Laminaria japonica }\end{array}$ & Exo & {$[21]$} \\
\hline Dendryphiella arenaria & n.d. & Intra-cellular & $\begin{array}{c}\text { Fucoidan from Fucus } \\
\text { vesiculosus and } \\
\text { Laminaria digitata }\end{array}$ & n.d. & {$[25]$} \\
\hline Flavobacteriaceae & n.d. & Extra-cellular & $\begin{array}{c}\text { Fucoidan from } \\
\text { Pevetia canaliculata }\end{array}$ & Endo & {$[24]$} \\
\hline Flavobacteriaceae & 67,000 & Extra-cellular & $\begin{array}{c}\text { Fucoidan from } \\
\text { Kjellmaniella crassifolia }\end{array}$ & Endo & {$[26]$} \\
\hline Littorina kurila & n.d. & Intra-cellular & $\begin{array}{l}\text { Fucoidan from } \\
\text { Fucus distichus }\end{array}$ & Disaccharides & {$[27]$} \\
\hline $\begin{array}{c}\text { Pseudoalteromonas } \\
\text { atlantica }\end{array}$ & n.d. & Extra-cellular & $\begin{array}{l}\text { Fucoidan from } \\
\text { brown seaweed }\end{array}$ & Exo & {$[28]$} \\
\hline Patinopecten yessoensis & 85,000 & Intra-cellular & $\begin{array}{c}\text { Fucoidan from } \\
\text { Nemacystus decipieus }\end{array}$ & Endo & {$[20]$} \\
\hline Pecten maximus & 200,000 & Extra-cellular & $\begin{array}{c}\text { Fucoidan from } \\
\text { Ascophyllum nodosum, }\end{array}$ & endo & [29] \\
\hline Pecten maximus & n.d. & Intra-cellular & $\begin{array}{c}\text { Fucoidan from } \\
\text { Ascophyllum nodosum }\end{array}$ & Releases L-fucose & {$[30]$} \\
\hline Pecten maximus & n.d. & Intra-cellular & $\begin{array}{c}\text { Sulfated } \\
\text { L-fucopyranoside }\end{array}$ & Sulfoesterase & {$[31]$} \\
\hline Vibrio sp. N5 & $\begin{array}{c}40,000- \\
68,000 \\
\end{array}$ & Extra-cellular & $\begin{array}{c}\text { Fucoidan from } \\
\text { Kjellmaniella crassifolia }\end{array}$ & Endo & {$[18]$} \\
\hline $\begin{array}{c}\text { Fucophilus } \\
\text { fucidanolyticus }\end{array}$ & n.d. & Intra-cellular & $\begin{array}{c}\text { Fucoidan from } \\
\text { Cladosiphon okamuranus }\end{array}$ & Endo & {$[26]$} \\
\hline Gram-negative bacterium & 67,000 & Extra-cellular & $\begin{array}{c}\text { Fucoidan from } \\
\text { Kjellmaniella crassifolia }\end{array}$ & Endo & {$[32]$} \\
\hline $\begin{array}{c}\text { Sphingomonas } \\
\text { paucimobilis } P F-1\end{array}$ & $\geq 132,000$ & Extra-cellular & $\begin{array}{c}\text { Fucoidan from Undaria } \\
\text { pinnatifida sporophyll }\end{array}$ & Endo & This study \\
\hline
\end{tabular}


FNase $\mathrm{S}$ was incubated with $1 \%$ fucoidan for three days at $45^{\circ} \mathrm{C}$ in $50 \mathrm{mM}$ sodium acetate buffer ( $\mathrm{pH}$ 5.6) containing $0.01 \%$ sodium azide. The reaction products were eluted with $50 \mathrm{mM}$ sodium nitrate at a flow rate of $0.5 \mathrm{~mL} / \mathrm{min}$. Each fraction was monitored for carbohydrates with the phenol- $\mathrm{H}_{2} \mathrm{SO}_{4}$ method at $490 \mathrm{~nm}$ using L-fucose as a reference. The arrow indicates the void volume at which the unhydrolyzed fucoidan and hydrolyzed products with larger molecular masses (over approximately $5000 \mathrm{Da}$ ) reached the upper exclusion limit of the gels. Only major peaks (1 to 7) were collected and examined for their monosaccharide compositions with high performance anion-exchange chromatography with pulsed amperometric detection (HPAEC-PAD) analyses.

\section{Experimental Section}

\subsection{Preparation of Fucoidan}

Miyeokgui fucoidan (MF) was extracted and purified as described previously [33]. Briefly, fucoidan was extracted from the dried sporophylls (called Miyeokgui in Korean) of Undaria pinnatifida (called Miyeok in Korean and Wakame in Japanese) that were collected from the southern coastal area of Wando, Korea, mainly through $0.1 \mathrm{~N} \mathrm{HCl}$ extraction and 75\% ethanol precipitation. The crude fucoidan obtained was further purified through DEAE-Cellulose column chromatography. Commercial fucoidan (tentatively named FF in this study) from alga Fucus vesiculosus was purchased from Sigma Chemical (St. Louis, MO, USA).

\subsection{Microorganism and Culture Conditions}

The growth of Sphingomonas paucimobilis PF-1 (KCTC 11130BP) was performed as previously reported by our group [14]. The cells were cultured in a minimal medium consisting of $0.5 \% \mathrm{MF}$ with $2 \%$ Bacto peptone in $\mathrm{dH}_{2} \mathrm{O}(\mathrm{pH} 7.0)$ at $30^{\circ} \mathrm{C}$ for 4 days on a shaking incubator (180 rpm, JEIO TECH Co., Seoul, Korea) and then centrifuged at $6000 \mathrm{rpm}, 4^{\circ} \mathrm{C}$ for $30 \mathrm{~min}$. The cells harvested were stored at $-20{ }^{\circ} \mathrm{C}$ and used for the purification of the fucoidanolytic enzymes.

\subsection{Production and Purification of Fucoidanase}

All experiments were performed at $4{ }^{\circ} \mathrm{C}$ unless otherwise stated. The cells (50 g, wet weight) were homogenized on ice using a Sonifier 450 (Branson, Danbury, CT, USA) for $1 \mathrm{~h}$ in $50 \mathrm{~mL}$ of $50 \mathrm{mM}$ sodium acetate buffer ( $\mathrm{pH}$ 5.6). The homogenate was centrifuged at 16,000 rpm for $40 \mathrm{~min}$ to remove the insoluble materials. The supernatant solution was gradually brought up to $40 \%(\mathrm{w} / \mathrm{v})$ saturation with $\left(\mathrm{NH}_{4}\right)_{2} \mathrm{SO}_{4}$ and then centrifuged at $16,000 \mathrm{rpm}$ for $30 \mathrm{~min}$ to remove the precipitates. Continuously, the supernatant solution was further brought to $80 \%(\mathrm{w} / \mathrm{v})$ saturation with $\left(\mathrm{NH}_{4}\right)_{2} \mathrm{SO}_{4}$ and precipitated overnight at $4{ }^{\circ} \mathrm{C}$. The precipitate was collected by centrifugation at $16,000 \mathrm{rpm}$ for $30 \mathrm{~min}$, dissolved in $10 \mathrm{~mL}$ of $50 \mathrm{mM}$ sodium acetate buffer ( $\mathrm{pH} 5.6)$, and dialyzed (10 kDa molecular weight cut off) extensively against $2 \mathrm{~L}$ of the same buffer for 3 days at $4{ }^{\circ} \mathrm{C}$ and stored at $-20{ }^{\circ} \mathrm{C}$. The dialyzed solution $(20 \mathrm{~mL})$ was loaded onto a column $(2.8 \times 30 \mathrm{~cm})$ of DEAE-Sepharose $(\mathrm{GE}$ Healthcare, Marlborough, MA, USA) and equilibrated with $10 \mathrm{mM}$ Tris- $\mathrm{HCl}$ buffer containing $10 \mathrm{mM}$ sodium chloride $(\mathrm{pH}$ 7.2). The column was washed with the same buffer and then was eluted with a linear gradient of $0-1 \mathrm{M}$ sodium chloride. The non-binding fractions on the DEAE-Sepharose were 
collected and dialyzed against 2 L $0.025 \mathrm{M}$ ethanolamine buffer ( $\mathrm{pH}$ 9.4). The concentration was applied onto a Mono P (GE Healthcare) column equilibrated with $0.025 \mathrm{M}$ ethanolamine buffer (pH 9.6) and then eluted with a linear gradient of Polybuffer 96 buffer (pH 7.0) (GE Healthcare). The apparent molecular weight of the purified enzyme was estimated with native PAGE and SDS-PAGE analyses using a 12\% polyacrylamide gel and Coomassie Brilliant Blue R-250 staining [34]. The molecular masses of the protein standard ranged from 10 to $170 \mathrm{kDa}$ and were prestained on a pro-stain Ladder (Fermentas, Hanover, MD, USA).

\subsection{Determination of the N-terminal Amino Acid Sequence}

The $N$-terminal amino acid residues of fucoidanase were determined using an Applied Biosystems 476A automatic protein sequencer (Amino Acid Sequencing Facility, Institute of Korea Basic Science, Daejeon, Korea). The amino acid sequence was compared with those available in SWISS-PROT and/or the Protein Data Bank.

\subsection{Effects of $p H$ and Temperature on Fucoidanase Activity and Stability}

The optimal temperature for fucoidanase activity was determined over the range of 25 to $55^{\circ} \mathrm{C}$ in $50 \mathrm{mM}$ sodium phosphate buffer $(\mathrm{pH} 6.0$ ) containing $0.5 \%$ of $\mathrm{MF}$ as the substrate. The thermal stability of the purified enzyme was tested by pre-incubating the enzyme at different temperatures $\left(25\right.$ to $55^{\circ} \mathrm{C}$ ) for 1 day. The remaining activities of fucoidanase were measured immediately after this treatment with the standard method mentioned previously. The activity of fucoidanase was determined by measuring the amount of reducing sugars released from the fucoidan with the Somogyi-Nelson method, using fucose as the standard [35]. One unit of fucoidanase activity was defined as the amount of enzyme (mg) that released $1 \mathrm{nmol}$ of reducing sugar per min. To determine the optimal $\mathrm{pH}$, the fucoidanase activity of the enzyme was studied at $45{ }^{\circ} \mathrm{C}$ in the following buffers: $50 \mathrm{mM}$ sodium acetate buffer ( $\mathrm{pH} 4.0$ and 5.0), $50 \mathrm{mM}$ sodium phosphate buffer ( $\mathrm{pH} 6.0)$, and $50 \mathrm{mM}$ Tris- $\mathrm{HCl}(\mathrm{pH}$ $7.0,8.0,9.0)$. The $\mathrm{pH}$ stability of the enzyme was measured based on the residual activity after pre-incubating the enzyme in the above buffer $(\mathrm{pH} 4.0-9.0)$ at $45^{\circ} \mathrm{C}$ for 1 day.

\subsection{Effects of Metal Ions on Fucoidanase Activity}

The effects of several metal ions on fucoidanase activity were examined in reaction mixtures supplemented with $\mathrm{NaCl}\left(\mathrm{Na}^{+}\right), \mathrm{MnSO}_{4}\left(\mathrm{Mn}^{2+}\right), \mathrm{KCl}\left(\mathrm{K}^{+}\right), \mathrm{CuSO}_{4}\left(\mathrm{Cu}^{2+}\right), \mathrm{CaCl}\left(\mathrm{Ca}^{2+}\right)$, and $\mathrm{BaCl}_{2}$ $\left(\mathrm{Ba}^{2+}\right)$ at final concentrations of $1 \mathrm{mM}$. The reactions were performed at the optimal $\mathrm{pH}$ and temperature over $72 \mathrm{~h}$ with $\mathrm{MF}(0.5 \%)$ as the substrate. The fucoidanase activity was determined with the Somogyi-Nelson method as described above.

\subsection{Determination of the Substrate Specificity}

The substrate specificity of the purified enzyme was determined using the following natural substrates: commercial fucoidan (FF) from the alga Fucus vesiculosus (Sigma), heparin, alginate, starch, laminarin, and dextran. The purified enzyme $(10 \mu \mathrm{g})$ was added to $1 \mathrm{~mL}$ of $50 \mathrm{mM}$ sodium phosphate buffer ( $\mathrm{pH} 6.0$ ) containing $0.5 \%$ substrates. The reactions were performed at the optimal $\mathrm{pH}$ 
and temperature over $72 \mathrm{~h}$. The fucoidanase activity was quantitatively determined by measuring the amount of reducing sugar released from the polysaccharide substrates with the Somogyi-Nelson method, using fucose or glucose as the standard [35].

\subsection{Determination of the Kinetic Parameters}

The hydrolysis kinetics of the purified enzyme on the intact fucoidan (MF) and commercial fucoidan (FF, Sigma) were determined at $\mathrm{pH} 6.0$ and $45^{\circ} \mathrm{C}$ with substrate concentrations that varied from 0 to $20 \mathrm{mM}$ and/or 0 to $30 \mathrm{mM}$, respectively; this step was followed by the standard enzyme assay described above. The $K_{\mathrm{m}}, V_{\max }$ and $K_{\text {cat }}$ values were obtained based on a Lineweaver-Burk plot and were expressed as the means of the three different experiments. This plot is widely used to determine important terms in enzyme kinetics, such as $K_{\mathrm{m}}$ and $V_{\max }$ for determining the type of enzyme inhibition by using competitive, non-competitive and uncompetitive inhibitors. In this plot, competitive inhibitors have the same $y$-intercept as uninhibited enzyme, since $V_{\max }$ is unaffected by competitive inhibitors. However, different slopes and $\mathrm{x}$-intercepts between the data sets can be seen in the same plot. On the other hand, non-competitive inhibition has plots with the same $x$-intercept with different slopes and $y$-intercepts. Subsequently, uncompetitive inhibition can cause different intercepts on both the $y$ - and $x$-axes. Herewith, our data simply showed in the case of uncompetitive inhibition, since no inhibitor was used to determine the kinetics of fucoidanase. These assays were set up in triplicates. If the plot of $1 / \mathrm{V}$ and $1 /$ (substrate) is linear, then the slope is equal to $1 / V_{\max }, 1 / K_{\mathrm{m}}$, and $K_{\text {cat }} / K_{\mathrm{m}}$.

\subsection{Size-Exclusion HPLC Analysis for Fucoidanase Activity}

Fucoidanase activity was determined by measuring the level of reducing sugars and confirmed with size-exclusion HPLC (Dionex Co., Sunnyvale, CA, USA) using a Shodex OHpak column (SB-806HQ, $8.0 \times 300 \mathrm{~mm}$, Showa Denko Co., Tokyo, Japan) under the established conditions, following 75\% ethanol precipitation. Next, the supernatant was vacuum-dried using a Speed-Vac (Module spin 40,

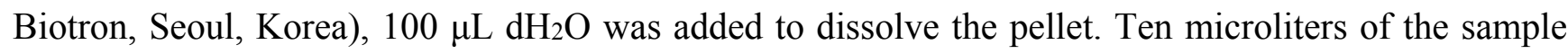
was injected, eluted with water at a flow rate of $0.8 \mathrm{~mL} / \mathrm{min}$ at $60{ }^{\circ} \mathrm{C}$ and detected with an evaporative light scattering detector (ELSD, Deerfield, IL, USA).

\subsection{Identification of the Galactofuco-Oligosaccharides}

The reaction mixture of MF and purified enzyme was fractionated through a Bio-Gel P-4 column $(1.5 \times 95 \mathrm{~cm})$, and each oligomer eluted from the column was analyzed for its monosaccharide composition and molecular mass. The reaction mixture of $10 \mathrm{~mL}$ of $50 \mathrm{mM}$ sodium phosphate buffer (pH 6.0) containing 1\% fucoidan and $10 \mathrm{~mL}$ of purified enzyme $(10 \mu \mathrm{g} / \mathrm{min})$ was incubated for 3 days at $45{ }^{\circ} \mathrm{C}$ in a shaking water bath $(120 \mathrm{rpm})$. After incubation, the enzyme was removed by centrifugation and the supernatant was concentrated by freeze drying. The dried material was dissolved in $5 \mathrm{~mL}$ of $\mathrm{dH}_{2} \mathrm{O}$ and precipitated with $75 \%$ ethanol. Next, the supernatant was vacuum-dried using a Speed-Vac. The dried material was dissolved in $1 \mathrm{~mL}$ of $50 \mathrm{mM}$ sodium nitrate and $0.5 \mathrm{~mL}$ of the material was applied to the Bio-Gel P-4 column and eluted at $0.5 \mathrm{~mL} / \mathrm{min}$ with the same solvent. The 
fractions containing carbohydrates were pooled together and freeze-dried to determine the monosaccharide compositions of the galactofuco-oligosaccharides. Pooled fractions were dissolved in $0.1 \mathrm{~mL}$ of $\mathrm{dH}_{2} \mathrm{O}$, an equal volume of $4 \mathrm{M}$ trifluoroacetic acid (TFA) was added, and the mixtures were allowed to stand for $4 \mathrm{~h}$ at $100{ }^{\circ} \mathrm{C}$ with gentle stirring. After the reaction, the mixture was filtered through a $0.45-\mu \mathrm{m}$ syringe filter and vacuum-dried using a Speed-Vac. The dried material was re-dissolved in $0.1 \mathrm{~mL}$ of $\mathrm{dH}_{2} \mathrm{O}$. The monosaccharide compositions of the TFA-hydrolyzed galactofuco-oligosaccharides were assessed with HPAEC-PAD (Dionex Co.) as described by Lee et al. [36].

\subsection{Statistical Analysis}

The statistical significances of the differences between the mean values were determined with Student's $t$-tests. The experimental values represent the means \pm the standard deviations.

\section{Conclusions}

In this study, we purified an enzyme (FNase S) that degrades Miyeokgui fucoidan (MF), which is a sulfated galactofucan, into smaller-sized galactofuco-oligosaccharides (1000-4000 Da), from a strain of Sphingomonas paucimobilis. Experiments involving the over-production and the purification of fucoidanases are thus of great interest, as is the processing of these enzymes to make them usable in industrial processes. The naturally occurring fucoidans require further structural elucidation to create a source of pharmaceutical drugs or any value-added raw materials for industrial processes. Additional knowledge about fucoidan-degrading enzymes will facilitate studies that aim to elucidate the structures of fucoidans and other fucoidan type polysaccharides and enable the production of lower-molecular weight functional galactofuco-oligosaccharides.

\section{Acknowledgments}

This work was supported by a grant from the Gyeonggi-do GRRC program (Project No. 2014-B03) of the Catholic University of Korea, for which the authors are thankful.

\section{Author Contributions}

Woo Jung Kim performed most of the purification and kinetic parameter analysis experiments as the first author; Joo Woong Park performed cell culture; Jae Kweon Park extracted and prepared fucoidan; Doo Jin Choi performed monosaccharide composition analysis; and Yong Il Park designed the experiments and wrote the paper as the corresponding author.

\section{Conflicts of Interest}

The authors declare no conflict of interest. 


\section{References}

1. Hoshino, T.; Hayashi, T.; Hayashi, J.; Lee, J.B.; Sankawa, U. An antivirally active sulfated polysaccharide from Sargassum horneri (TURNER) C. AGARDH. Biol. Pharm. Bull. 1998, 21, 730-734.

2. Cumashi, A.; Ushakova, N.A.; Preobrazhenskaya, M.E.; D’Incecco, A.; Piccoli, A.; Totani, L.; Tinari, N.; Morozevich, G.E.; Berman, A.E.; Bilan, M.I.; et al. A comparative study of the anti-inflammatory, anticoagulant, anti-angiogenic and anti-adhesive activities of nine different fucoidans from brown seaweeds. Glycobiology 2007, 17, 541-552.

3. Alekseyenko, T.V.; Zhanayeva, S.Y.; Venediktova, A.A.; Zvyagintseva, T.N.; Kuznetsova, T.A.; Besednova, N.N.; Korolenko, T.A. Antitumor and antimetastatic activity of fucoidan, a sulfated polysaccharide isolated from the Okhotsk sea Fucus evanescens brown alga. Bull. Exp. Biol. Med. 2007, 147, 730-732.

4. Hahnenberger, R.; Jakobson, A.M. Antiangiogenic effect of sulfated glycosaminoglycans and polysaccharides in the chick embryo chorioallantoic membrane. Glycoconj. J. 1991, 8, 350-353.

5. Chevolot, L.; Foucault, A.; Chaubet, F.; Kervarec, N.; Sinquin, C.; Fisher, A.M.; Boisson-Vidal, C. Further data on the structure of brown seaweed fucans: Relationships with anticoagulant activity. Carbohydr. Res. 1999, 319,154-165.

6. Usov, A.I.; Smirnova, G.P.; Bilan, M.I.; Shashkov, L.S. Polysaccharides of brown algae. Bioorg. Khim. 1998, 24, 437-445.

7. Mulloy, B.; Ribeiro, A.C.; Alves, A.P.; Vieira, R.P.; Mourão, P.A.S. Sulfated fucans from echinoderms have a regular tetrasaccharide repeating unit defined by specific patterns of sulfation at the $O-2$ and $O-4$ positions. J. Biol. Chem. 1994, 269, 22113-22123.

8. Berteau, O.; Mulloy, B. Sulfated fucans, fresh perspectives: Structures, functions, and biological properties of sulfated fucans and an overview of enzymes active toward this class of polysaccharides. Glycobiology 2003, 13, 29R-40R.

9. Silchenko, A.S.; Kusaykin, M.I.; Kurilenko, V.V.; Zakharenko, A.M.; Isakov, V.V.; Zaporozhets, T.S.; Gazha, A.K.; Zvyagintseva, T.N. Hydrolysis of Fucoidan by Fucoidanase Isolated from the Marine Bacterium, Formosa algae. Mar. Drugs 2013, 11, 2416-2430.

10. Ji, J.; Wang, L.C.; Wu, H.; Luan, H.M. Bio-function Summary of Marine Oligosaccharides. Int. J. Biol. 2011, 3, 74-86.

11. Holtkamp, A.D.; Kelly, S.; Ulber, R.; Lang, S. Fucoidans and fucoidanases-focus on thchniques for molecular structure elucidation and modification of marine polysaccharides. Appl. Microbiol. Biotechnol. 2009, 82, 1-11.

12. Courtois, J. Oligosaccharides from land plants and algae: Production and applications in therapeutics and biotechnology. Curr. Opin. Microbiol. 2009, 12, 261-273.

13. Bakunina, I.; Nedashkovskaya, O.I.; Alekseeva, S.A.; Ivanova, E.P.; Romanenko, L.A.; Gorshkova, N.M.; Isakov, V.V.; Zvyagintseva, T.N.; Mikhailov, V.V. Degradation of fucoidan by the marine proteobacterium Pseudoalteromonas citrea. Mikrobiologiia 2002, 71, 49-55.

14. Kim, W.J.; Kim, S.M.; Lee, Y.H.; Kim, H.G.; Kim, H.K.; Moon, S.H.; Suh, H.H.; Jang, K.H.; Park, Y.I. Isolation and characterization of marine bacterial strain degrading fucoidan from Korean Undaria pinnatifida sporophylls. J. Microbiol. Biotechnol. 2008, 18, 616-623. 
15. Synytsya, A.; Kim, W.J.; Kim, S.M.; Pohl, R.; Synytsya, A.; Kvasnicka, F.; Čopíková, J.; Park, Y.I. Structure and antitumour activity of fucoidan isolated from sporophyll of Korean brown seaweed Undaria pinnatifida. Carbohydr. Polym. 2010, 81, 41-48.

16. Laemmli, U.K. Cleavage of structural proteins during assembly of head of bacteriophage T4. Nature 1970, 227, 680-685.

17. Colin, S.; Deniaud, E.; Jam, M., Descamps, V.; Chevolot, Y.; Kervarec, N.; Yvin, J.C.; Barbeyron, T.; Michel, G.; Kloareg, B. Cloning and biochemical characterization of the fucanase FcnA: Definition of a novel glycoside hydrolase family specific for sulfated fucans. Glycobiology 2006, 16, 1021-1032.

18. Furukawa, S.; Fujikawa, T.; Koga, D.; Ide, A. Purification and some properties of exo-type fucoidanases from Vibrio sp. N-5. Biosci. Biotechnol. Biochem. 1992, 56, 1829-1834.

19. Doi, R.H.; Kosugi, A. Plant-cell-wall-degrading enzyme complexes. Nat. Rev. 2004, 2, 541-551.

20. Kitamura, K.; Matsuo, M.; Yasui, T. Enzymatic degradation of fucoidan by fucoidanase from the hepatopancreas of Patinopecten yessoensis. Biosci. Biotechnol. Biochem. 1992, 56, 490-494.

21. Bakunina, I.Yu.; Shevchenko, L.S.; Nedashkovskaya, O.I.; Shevchenko, N.M.; Alekseeva, S.A.; Mikhailov, V.V.; Zvyagintseva, T.N. Screening of marine bacteria for fucoidanases. Microbiology 2000, 69, 303-308.

22. Sakai, T.; Kimura, H.; Kojima, K.; Ikai, K.; Akiyoshi, S.; Nakanishi, Y.; Kato, I. Oligosaccharides manufacture by hydrolysis of fucoidan. Chem. Abstr. 1997, 126, 113.

23. Gonzalez, J.M.; Weiner, R.M. Phylogenetic characterization of marine bacterium strain 2-40, a degrader of complex polysaccharides. Int. J. Syst. Evol. Microbiol. 2000, 50, 831-834.

24. Descamps, V.; Colin, S.; Lahaye, M.; Jam, M.; Richard, C.; Potin, P.; Barbeyron, T.; Yvin, J.C.; Kloareg, B. Isolation and culture of a marine bacterium degrading the sulfated fucans from marine brown algea. Mar. Biotechnol. 2005, 8, 1-13.

25. Kelly, S.; Holtkamp, A.; Poth, S.; Lang, S.; Ulber, R. Untersuchungen zur potenziellen fucoidanase-Aktivität von Dendryphiella Arenaria. Chem. Ing. Tech. 2008, 80, 399-403.

26. Sakai, T.; Ishizuka, K.; Shimanaka, K.; Ikai, K.; Kato, I. Structures of oligosaccharides derived from Cladosiphon okamuranus fucoidan by digestion with marine bacterial enzymes. Mar. Biotechnol. 2003, 5, 536-544.

27. Bilan, M.I.; Kusaykin, M.I.; Grachev, A.A.; Tsvetkova, E.A.; Zvyagintseva, T.N.; Nifantiev, N.E.; Usov, A.I. Effect of enzyme preparation from the marine mollusk Littorina kurila on fucoidan from the brown alga Fucus distichus. Biochemistry (Mosc.) 2005, 70, 1321-1326.

28. Yaphe, W.; Morgan, K. Enzymic hydrolysis of fucoidin by Pseudomonas atlantica and Pseudomonas carrageenovora. Nature 1959, 183, 761-762.

29. Berteau, O.; McCort, I.; Goasdoue, N.; Tissot, B.; Daniel, R. Characterization of a new alpha-L-fucosidase isolated from the marine mollusk Pecten maximus that catalyzes the hydrolysis of alpha-L-fucose from algal fucoidan (Ascophyllum nodosum). Glycobiology 2002, 12, 273-282.

30. Daniel, R.; Berteau, O.; Jozefonvicz, J.; Goasdoue, N. Degradation of algal (Ascophyllum nodosum) fucoidan by an enzymatic activity contained in digestive glands of the marine mollusk Pecten maximus. Carbohyd. Res. 1999, 322, 291-297. 
31. Daniel, R.; Berteau, O.; Chevolot, L.; Varenne, A.; Gareil, P.; Goasdoue, N. Regioselective desulfation of sulfated L-fucopyranoside by a new sulfoesterase from the marine mollusk Pecten maximus: Application to the structural study of algal fucoidan (Ascophyllum nodosum). Euro. J. Biochem. 2001, 268, 5617-5626.

32. Sakai, T.; Kawai, T.; Kato, I. Isolation and characterization of a fucoidan-degrading marine bacterial strain and its fucoidanase. Mar. Biotechnol. 2004, 6, 335-346.

33. Kim, W.J.; Kim, S.M.; Kim, H.G.; Oh, H.R.; Lee, K.B.; Lee, Y.K.; Park, Y.I. Purification and anticoagulant activity of a fucoidan from Korean Undaria pinnatifida sporophyll. Algae 2007, 22, $247-252$.

34. George, V.; Diwan, A.M. Simultaneous staining of proteins during polyacrylamide gel electrophoresis in acidic gels by countermigration of Coomassie brilliant blue R-250. Anal. Biochem. 1983, 132, 481-483.

35. Somogyi, M. Notes on sugar determination. J. Biol. Chem. 1952, 195, 19-23.

36. Lee, Y.K.; Lim, D.J.; Lee, Y.H.; Park, Y.I. Variation in fucoidan contents and monosaccharide compositions of Korean Undaria pinnatifida (Harvey) suringar (Phaeophyta). Algae 2006, 21, $157-160$.

(C) 2015 by the authors; licensee MDPI, Basel, Switzerland. This article is an open access article distributed under the terms and conditions of the Creative Commons Attribution license (http://creativecommons.org/licenses/by/4.0/). 